\title{
MFO Induction of Three Australian Fish Species
}

\author{
Brent James Smith, Marthe Monique Gagnon* \\ Department of Applied Biology and Biotechnology, Royal Melbourne Institute of Technology, City Campus, \\ Melbourne, Vic. 3001, Australia
}

Received 27 January 1998; revised 26 June 1998; accepted 27 August 1998

\begin{abstract}
The use of mixed function oxygenase (MFO) enzymes as a biomarker of pollution in Port Phillip Bay was investigated in three indigenous fish species, sand flathead (Plathycephalus bassensis), bluethroat wrasse (Notalabrus tetricus), and sixspine leatherjacket (Meuschenia freycineti). Investigation of the relative MFO induction potential was performed by intraperitoneally injecting each experimental fish species with $100 \mu \mathrm{g} / \mathrm{kg}$ of 3,3',4,4',5-pentachlorobiphenyl (PCB 126) using corn oil as a carrier. Hepatic induction was fluorimetrically measured by the activity of 7 -ethoxyresorufin $O$-deethylase (EROD) activity 10 days post-injection. Of the three species tested, the sand flathead was selected as the most suitable indicator species for its high MFO induction potential and desirable characteristics related to its population biology. Bluethroat wrasse appeared relatively uninducible by PCB 126 , while sixspine leatherjacket demonstrated a medium induction potential but was unsuitable as a biomonitoring tool because of its scarcity and distribution limited to reef beds. (c) 2000 by John Wiley \& Sons, Inc. Environ Toxicol 15: 1-7, 2000
\end{abstract}

Keywords: MFO; EROD; sixspine leatherjacket; sand flathead; bluethroat wrasse; PCB

\section{INTRODUCTION}

Port Phillip Bay is a large embayment of about 1930 $\mathrm{km}^{2}$, with a coastline of approximately $264 \mathrm{~km}$ (Fig. 1). It is situated on the south coast of central Victoria, Australia, connected to Bass Strait and the Southern Ocean through a relatively narrow opening. Port Phillip Bay supports both commercial and recreational fisheries; consumption of fish from the bay is considerable and therefore, the health of the fish populations is of economic, social, and political importance.

Melbourne, Victoria's largest city with a population in excess of 3 million people is located at the top of the

Correspondence to: M. M. Gagnon, Ph.D.; School of Environmental Biology, Curtin University of Technology, Perth, WA 6845 Australia; Tel: +61 89266 3723; Fax: +61 89266 2495; e-mail: rgagnonm@alpha2.curtin.edu.au

* Contract grant sponsor: RMIT Faculty of Biomedical and Health Sciences research grant. bay and is a major port in Australia. Geelong, the second largest city in the state is located in the west of the bay and has a population of 200 thousand. Both of these locations, but in particular the Geelong-Corio Bay area has significant industrial activity along its shores (Holdway et al., 1994).

Suprisingly, very little is known about the health of fish populations inhabiting Port Phillip Bay despite known significant contamination of water, sediments, and biota by such contaminants as mercury (Fabris et al., 1992; Phillips et al., 1992), polycyclic aromatic hydrocarbons (PAHs) (Smith et al., 1991; Phillips et al., 1992), and organochlorines including pesticides and polychlorinated biphenyls (PCBs). According to the levels of toxicants reported for the bottom sediments during the most recent Port Phillip Bay environmental study, sublethal effects of exposure in fish are most likely to occur in the most polluted areas, notably Corio Bay, Hobsons Bay, and the Mordialloc area 


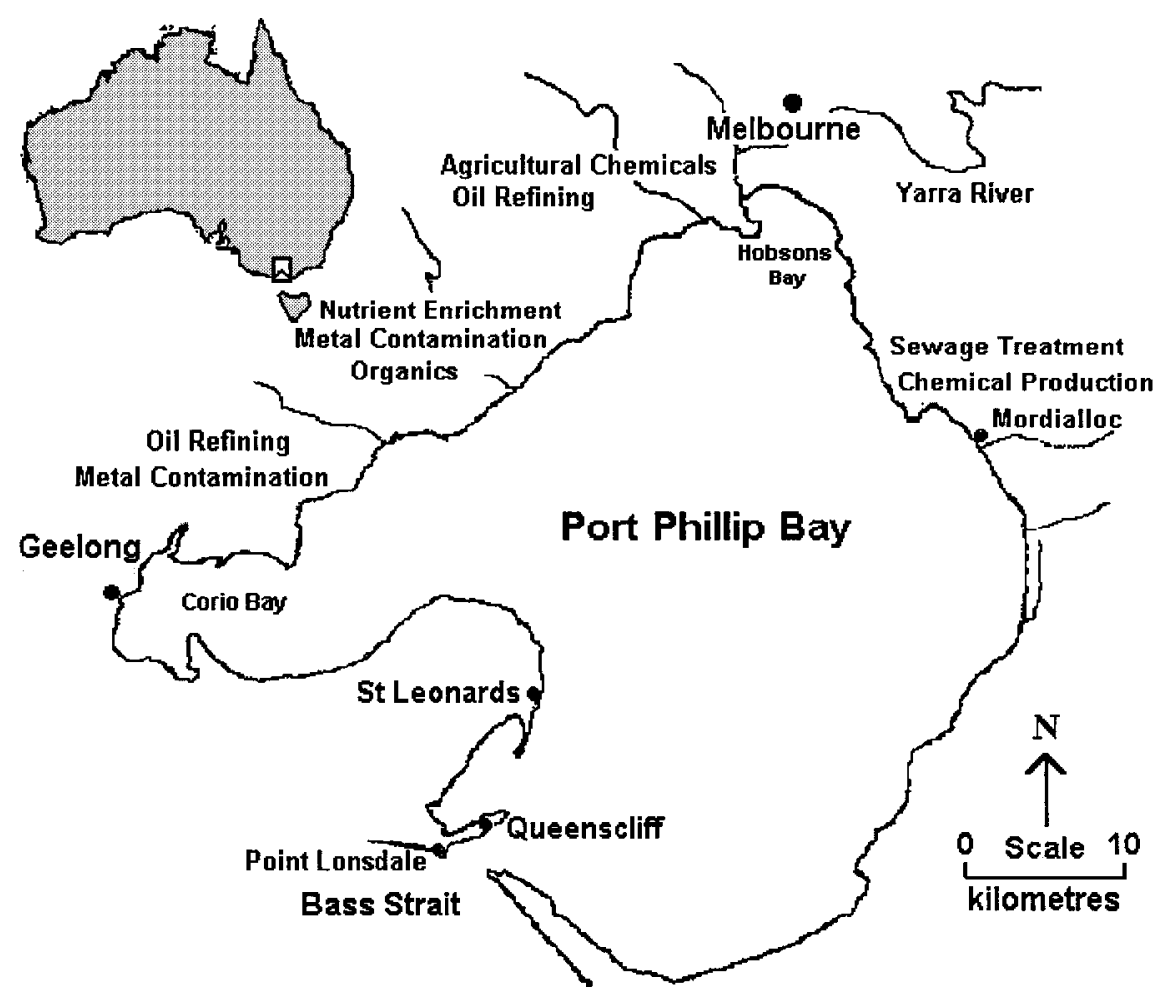

Fig. 1. Potential sources of chemical contamination and contaminated locations in Port Phillip Bay, Victoria, Australia. Fish were sampled throughout the Bay. (Adapted from Holdway et al., 1995.)

(Harris et al., 1996). In order to adequately protect the aquatic life of Port Phillip Bay, it is fundamental to identify fish species sensitive enough to be used as bioindicators of pollution and environmental health in future monitoring of the Bay.

Attempts to detect impacts on marine organisms at population and community levels has led to suggestions that changes in various physiological/biochemical parameters may be of value as early warning systems for identifying and delineating the sublethal effects of pollutants (Payne et al., 1987). One group of biological tools that are useful for monitoring effects of pollutants have been collectively referred to as biomarkers, defined as any biological, histological and/or physiological alterations or manifestations of stress (Holdway et al., 1995). The use of biomarkers in environmental pollution studies involves monitoring a suite of selected stress responses in order to (1) assess the effects of sublethal stress on fish, (2) predict future trends (early warning indicators), and (3) obtain insights into causal relationships between stress and effects at the individual, and at the community and ecosystem level (Adams et al., 1989). One group of sensitive biomarkers which have been proposed are mixed function oxygenases (MFOs) in fish livers.
Serum sorbitol dehydrogenase (SDH), another sensitive biomarker, has proven to be a good, reliable indicator of sublethal hepatotoxicity in studies of chemical effects on fish (Dixon et al., 1987; Holdway et al., 1994). SDH is an enzyme found almost exclusively in the liver (Ozretic and Krajnovic-Ozretic, 1993) which catalyzes the reversible interconversion of fructose and the polyhydric alcohol sorbitol (Dixon et al., 1987). $\mathrm{SDH}$ is not elevated in other diseased organs, but is specific to hepatic damage (Dixon et al., 1987), and therefore can be used as an effective indicator of liver function.

In a monitoring program SDH can be used in conjunction with MFOs, and can explain discrepancies in measured MFO levels due to cellular liver damage. Morever, SDH activity is not affected by conditions often affecting MFO induction such as fasting, sex, and the use of a carrier such as corn oil (Dixon et al., 1987).

Large variations in induction capabilities of MFO enzymes in various fish species have been reported using very similar protocols and inducing agents (Kloepper-Sams and Benton, 1994; Focardi et al., 1995). In Australia the use of biomarkers in aquatic animals to monitor the bioavailability of anthropogenic chemicals is a relatively unexplored field, with very few 
studies correlating exposure with response (Holdway et al., 1994). Only three fish species, the sand flathead (Platycephalus bassensis) (Holdway et al., 1995), carp (Cyprinus carpio) (Ahokas et al., 1994) and spikey globefish (Atopomycterus nicthemerus) (Holdway et al., 1993) have been used in field trials.

The present study investigated the MFO induction potential of three common Australian native fish species, the sand flathead, the bluethroat wrasse (Notalabrus tetricus) and the sixspine leatherjacket (Meuschenia freycineti). Investigation of the relative induction potential was performed by intraperitoneally (i.p.) injecting each experimental fish species with 100 $\mu \mathrm{g} / \mathrm{kg}$ of 3,3',4,4',5-pentachlorobiphenyl (PCB 126) diluted in corn oil. Atlantic salmon (Salmo salar) used as a positive control was also injected with the same dose of PCB 126. The aim of this study was to identify the most suitable native fish species to be used as a bioindicator in routine environmental biomonitoring in Australian waters common to these fish species.

\section{MATERIALS AND METHODS}

\section{Chemicals}

Bovine Serum Albumin (BSA), ethoxyresorufin, tricaine methanesulfonate (MS-222), Hepes, corn oil, and sorbitol deyhdrogenase (SDH) assay kit were obtained from Sigma, USA. 3,3',4,4',5-pentachlorobiphenyl was purchased from AccuStandard, USA, while potassium chloride (KCl) was obtained from UNIVAR, USA. Resorufin was purchased from Kodak, USA, and NADPH was obtained from Boehringer Mannheim, Germany. All solvents used were of analytical grade.

\section{Fish Collection and Acclimation}

Approximately 30 fish of each species were used. All fish were acclimatized to laboratory conditions for a minimum of 7 days. Some fish received longer periods of acclimation due to difficulties in collecting a sufficient number of specimens. Fish were kept throughout the experiment in 1000 liter tanks with a seawater flow through rate of 10 liters per minute. The seawater was pumped directly from and into Port Phillip Bay. A 12 hour light/12 hour dark regime was used. Fish were not fed for 2 days prior to and during experimentation. Physiochemical characteristics of the water and experimentation dates for each species are listed in Table I.

Atlantic salmon were obtained from Salmon Enterprises of Tasmania (SALTAS), and were all immature females (age $1+$ years). These fish were fed daily with salmon pellets. Some (five) Atlantic salmon died during the 10 days post injection in the Corn Oil Control or PCB 126 groups. Pathological examination of skin ulcers showed infection by Vibrio or Flexibacter species. There was no indication that the bacteria had spread to fish that survived 10 days post injection.

All sand flathead were caught by line and debarbed hook in a channel $1 \mathrm{~km}$ directly east of St. Leonards in Port Phillip Bay. Method of capture allowed fast and relatively stress free transfer of fish to transportation tanks. Fish were fed twice weekly with pilchards during acclimation.

Sixspine leatherjackets were caught by trap using squid heads as bait in reefs 100 meters out from Dog Beach, Point Lonsdale. During acclimation, fish were fed twice weekly with squid head.

Bluethroat wrasse were caught by a commercial fisherman in Port Phillip Bay using hook and line. All fish were fed twice weekly with squid heads during acclimation.

Sex and seasonal variation have been described as being a cause of variability in measured mixed function oxygenase levels, particularly in ripe females (Gagnon et al., 1994). In this study every effort was made to collect and sample fish outside of their reproductive seasons.

\section{Preparation of $3,3^{\prime} 4,4^{\prime}, 5$-pentachlorobiphenyl}

$3,3^{\prime} 4,4^{\prime}, 5$-pentachlorobiphenyl $(5 \mathrm{mg})$ was dissolved in 1 $\mathrm{mL}$ isooctane and then diluted in $49 \mathrm{~mL}$ corn oil to give a final concentration of $100 \mu \mathrm{g} / \mathrm{mL}$. Two experi-

TABLE I. Summary of water parameters and experimentation times

\begin{tabular}{lcccccc}
\hline Species & Time of study & $\begin{array}{c}\text { Temperature } \\
\left({ }^{\circ} \mathrm{C}\right)\end{array}$ & $\begin{array}{c}\text { Salinity } \\
(\mathrm{ppt})\end{array}$ & $\begin{array}{c}\text { Dissolved } \\
\text { oxygen } \\
(\mathrm{mg} / \mathrm{L})\end{array}$ & $\begin{array}{c}\text { Conductivity } \\
(\mathrm{mS} / \mathrm{cm})\end{array}$ & $\mathrm{pH}$ \\
\hline $\begin{array}{c}\text { Atlantic } \\
\text { salmon }\end{array}$ & August 1997 & 13.2 & 36.3 & 7.44 & 54.7 & 8.09 \\
$\begin{array}{l}\text { Sand flathead } \\
\begin{array}{l}\text { Sixspine } \\
\text { leatherjacket }\end{array}\end{array}$ & $\begin{array}{c}\text { September 1997 } \\
\text { April 1997 }\end{array}$ & 13.2 & 35.8 & 7.32 & 54.3 & 8.08 \\
$\begin{array}{c}\text { Bluethroat } \\
\text { wrasse }\end{array}$ & October 1997 & 15.6 & 37.0 & 7.80 & 55.6 & 8.05 \\
\hline
\end{tabular}


mental concentrations, $50 \mu \mathrm{g} \mathrm{PCB} / \mathrm{kg}$ and $100 \mu \mathrm{g}$ $\mathrm{PCB} / \mathrm{kg}$, were i.p. injected to a small number of sand flathead and sixspine leatherjacket (three fish/ concentration) to determine the ability of the fish to cope with high concentrations of chemicals. As fish remained healthy for 10 days at the highest concentration, a dose of $100 \mathrm{mg} \mathrm{PCB} / \mathrm{kg}$ was selected for injections of all other fish in an attempt to maximize EROD induction response.

\section{Fish Dissection and Injections}

Each species was divided into three groups of approximately 10 randomly selected fish, except for the sixspine leatherjacket where only 18 fish were obtained despite intense fishing efforts. Fish were immersed in an anaesthetic solution of MS-222 (70 mg/Liter) for approximately 3 minutes prior to dissection or injection. For each species, the experiment was initiated by the dissection of 10 specimens (Time Zero Control) as follows: total weight and standard length were recorded, a blood sample was collected from the caudal artery and allowed to clot on ice for approximately $15 \mathrm{~min}$ utes, followed by a centrifugation at $3500 \mathrm{rpm}$ for 5 minutes at $5^{\circ} \mathrm{C}$ in a Heraeus Sepatech Megafuge 1.0R. Serum was collected and stored at $-80^{\circ} \mathrm{C}$ for $\mathrm{SDH}$ determinations. The fish was killed by a blow on the head, and the liver was excised, weighed, rinsed with $0.15 \mathrm{M}$ ice cold $\mathrm{KCl}$ and immediately frozen in liquid nitrogen for EROD determinations.

A second group of 10 fish were i.p. injected with corn oil only (Corn Oil Control), while the third group of 10 fish was i.p. injected with $100 \mu \mathrm{g} / \mathrm{kg}$ of $3,3^{\prime}, 4,4^{\prime}, 5$-pentachlorobiphenyl (PCB 126) diluted in corn oil. These two groups were then sampled at 10 days post-injection in the same manner as the Time Zero Control fish.

\section{EROD Assay}

EROD determinations were essentially performed according to Hodson et al. (1991). After initial freezing in liquid nitrogen, livers were stored in a $-80^{\circ} \mathrm{C}$ freezer until analyzed. Livers were thawed on ice and homogenized. The homogenate was centrifuged at $12,000 \mathrm{rpm}$ for 20 minutes at $4^{\circ} \mathrm{C}$, the post mitochondrial suspension (PMS) was collected for immediate use.

The reaction mixture contained $0.1 \mathrm{M}$ Hepes buffer, $\mathrm{pH} 7.8,50 \mu \mathrm{l}, 154 \mathrm{mg} / \mathrm{mL} \mathrm{MgSO}_{4}, 2 \mathrm{mg} \mathrm{BSA}, 0.5 \mathrm{mM}$ NADPH and $50 \mu$ l PMS. The reaction was initiated by addition of ethoxyresorufin, incubated for 2 minutes at $25^{\circ} \mathrm{C}$ and terminated by addition of $2.5 \mathrm{~mL}$ of methanol.

Standards and samples were centrifuged to precipitate proteins and the fluorescence of the supernatant was read on a Hitachi F-4500 Fluorescence Spectrophotometer at excitation/emission wavelengths of $530 / 585 \mathrm{~nm}$.

Protein content of the PMS was analyzed using the method of Lowry et al. (1951) and measured on a Hitachi U-2000 Spectrophotometer. EROD activity is expressed as picomoles of resorufin produced per minute, per $\mathrm{mg}$ of total protein (pmol resorufin/mg protein/min) in the PMS.

\section{SDH Assay}

Serum SDH activity was analyzed using the Sigma Diagnostics kit 50-UV. The decrease in absorbence at $340 \mathrm{~nm}$ of the reaction mixture was recorded at $25^{\circ} \mathrm{C}$ for 5 minutes against a water reference in a Hitachi U-2000 UV double beam spectrophotometer. An SDH control sample was also read every 10 samples to ensure the assay was performing within guidelines.

\section{Statistical Analyses}

Normality and heteroscedasticity were assessed by visual inspection of scattergrams of residuals versus fitted $y$ as recommended by Zar (1984). EROD and SDH data were log-transformed to achieve normality. $t$ tests were carried out to identify differences between sexes within each experimental group for each species. Treatments were compared using a one-way analysis of variance (ANOVA). When significant differences between treatments were found $(\mathrm{p} \leqslant 0.05)$, a Tukey post-hoc test was used to identify differences between the means.

\section{RESULTS}

EROD activity in the PCB injected Atlantic salmon was significantly induced relative to the Time Zero and Corn Oil Control fish (Table II) $(p<0.001$ in both cases). There was no significant difference $(p=0.99)$ between Time Zero and Corn Oil Control groups. Time zero baseline EROD activity of 15.4 pmol resorufin /mg protein/min was measured. No significant difference $(p=0.09)$ was observed in SDH activity between any treatment with SDH levels being 5.3, 4.3, and $6.2 \mathrm{mU}$ for Time Zero Control, Corn Oil Control, and PCB 126 groups, respectively.

Results from MFO determination were also pooled for male and female sand flathead as there were no significant differences $(p=0.10,0.83,0.91$ for Time Zero Control, Corn Oil Control, and PCB 126 groups, respectively) between sexes. There were significant differences however, in EROD activity between the PCB 126 group and both the Time Zero Control and Corn 
TABLE II. EROD and SDH activity of species receiving no injection (Time Zero Control), corn oil (Corn Oil Control) or $100 \mu \mathrm{g} / \mathrm{kg}$ PCB 126 in corn oil (PCB 126)

\begin{tabular}{|c|c|c|c|c|}
\hline Fish species & Treatment & Sex ratio $^{c}$ & 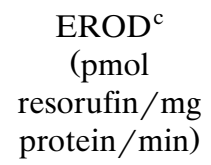 & $\begin{array}{l}\mathrm{SDH}^{\mathrm{c}} \\
(\mathrm{mU})\end{array}$ \\
\hline \multirow[t]{3}{*}{ Atlantic salmon } & $\begin{array}{c}\text { Time Zero } \\
\text { Control }\end{array}$ & Imm. F only & $15.4^{\mathrm{a}}(10,2.7)$ & $5.3^{\mathrm{a}}(10,0.4)$ \\
\hline & Corn Oil Control & Imm. F only & $15.3^{\mathrm{a}}(6,3.2)$ & $4.3^{\mathrm{a}}(6,0.4)$ \\
\hline & PCB 126 & Imm. F only & $809^{\mathrm{b}}(9,79.1)$ & $6.2^{\mathrm{a}}(9,0.7)$ \\
\hline \multirow[t]{3}{*}{ Sand flathead } & $\begin{array}{c}\text { Time Zero } \\
\text { Control }\end{array}$ & $6 \mathrm{M}: 4 \mathrm{~F}$ & $50.8^{\mathrm{a}}(10,7.4)$ & $5.7^{\mathrm{a}}(10,0.6)$ \\
\hline & Corn Oil Control & $7 \mathrm{M}: 6 \mathrm{~F}$ & $34.4^{\mathrm{a}}(13,1.9)$ & $9.7^{\mathrm{a}}(12,1.7)$ \\
\hline & PCB 126 & $5 \mathrm{M}: 4 \mathrm{~F}$ & $693^{\mathrm{b}}(9,109)$ & $8.5^{\mathrm{a}}(9,1.4)$ \\
\hline \multirow[t]{3}{*}{$\begin{array}{l}\text { Sixspine } \\
\text { leatherjacket }\end{array}$} & $\begin{array}{l}\text { TIme Zero } \\
\text { Control }\end{array}$ & $4 \mathrm{M}: 6 \mathrm{~F}$ & $152^{\mathrm{a}}(10,27.1)$ & $7.8^{\mathrm{a}}(10,1.3)$ \\
\hline & Corn Oil Control & $4 \mathrm{~F}$ & $118^{\mathrm{a}}(4,17.1)$ & $6.5^{\mathrm{a}}(4,1.3)$ \\
\hline & РCB 126 & $4 \mathrm{~F}$ & $315^{\mathrm{b}}(4,53.5)$ & $10.1^{\mathrm{a}}(4,2.6)$ \\
\hline \multirow[t]{3}{*}{$\begin{array}{l}\text { Bluethroat } \\
\text { wrasse }\end{array}$} & $\begin{array}{c}\text { Time Zero } \\
\text { Control }\end{array}$ & $1 \mathrm{M}: 6 \mathrm{~F}$ & $222^{\mathrm{a}}(7,52.5)$ & $3.3^{\mathrm{a}}(6,0.7)$ \\
\hline & Corn Oil Control & $1 \mathrm{M}: 9 \mathrm{~F}$ & $256^{\mathrm{a}}(10,49.0)$ & $3.2^{\mathrm{a}}(10,0.5)$ \\
\hline & PCB 126 & $9 \mathrm{~F}$ & $284^{\mathrm{a}}(9,76.5)$ & $3.9^{\mathrm{a}}(9,0.4)$ \\
\hline
\end{tabular}

\footnotetext{
${ }^{\mathrm{a}, \mathrm{b}}$ Values are expressed as mean $(n, \mathrm{SE})$. Values within columns with a superscript letter in common are not significantly different $(p \leqslant 0.05)$ based on Tukey post-hoc test.

${ }^{\mathrm{c}}$ Imm., Immature; M, male; F, female (no significant difference between sexes so results are pooled); EROD, ethoxyresorufin $O$-deethylase; SDH, sorbitol dehydrogenase.
}

Oil Control groups $(p<0.001$ in both cases). Enzyme induction by PCB 126 equated to a 20 -fold increase in EROD activity compared to the Corn Oil Control group (Table II). There was no significant difference ( $p=0.16)$ between the Time Zero Control and Corn Oil Control groups with the baseline EROD activity being $50.8 \mathrm{pmol}$ resorufin/mg protein/min. Again, no significant differences $(p=0.11)$ were found in $\mathrm{SDH}$ activity in any group with levels of 5.7, 9.7, and $8.5 \mathrm{mU}$ in Time Zero Control, Corn Oil Control, and PCB 126 groups, respectively.

All sixspine leatherjackets injected with PCB 126 or corn oil were female with only two sexually mature fish (not reproductively active), while four out of ten fish were male in the Time Zero Control group. $t$ test confirmed no significant difference in hepatic EROD activity between males and female sixspine leatherjackets in the Time Zero Control group ( $p=0.336)$. Therefore, sexes were pooled in this group for subsequent analysis. Baseline EROD levels in this species, as represented by the Time Zero Control group were 152 pmol resorufin/mg protein/min, which was not significantly different from the Corn Oil injected leatherjackets $(\mathrm{EROD}=118 \mathrm{pmol}$ resorufin $/ \mathrm{mg}$ protein $/ \mathrm{min}, p$ $=0.83$ ) (Table II). Injections with PCB 126 significantly increased EROD activity (EROD $=315$ pmol resorufin $/ \mathrm{mg}$ protein $/ \mathrm{min}$ ) relative to Time Zero and Corn Oil only treatments ( $p=0.026$ and 0.025 , respectively). There were no significant differences $(p=0.58)$ in SDH activity between any of the three groups with SDH levels being 7.8, 6.5, and $10.1 \mathrm{mU}$ in the Time Zero Control, Corn Oil Control, and PCB 126 groups, respectively.

As with the sand flathead and sixspine leatherjacket, there was no significant difference $(p=0.37,0.48$ for Time Zero Control and Corn Oil Control groups, respectively) between sexes in any group for bluethroat wrasse, so results were pooled for further statistical analysis. The PCB injected group was composed entirely of immature females. There were no significant differences $(p=0.96)$ between any of the groups in EROD activity (Table II). The baseline level was com- 
paratively high at $222 \mathrm{pmol}$ resorufin/mg protein/min. There was no significant difference $(p=0.35)$ in SDH activity in any group with levels of 3.3, 3.2, and $3.9 \mathrm{mU}$ in Time Zero Control, Corn Oil Control, and PCB 126 groups, respectively.

\section{DISCUSSION}

We observed a very active mixed function oxygenase system in Atlantic salmon with increases of 53-fold in the PCB 126 injected group relative to the Corn Oil injected group. This result shows that the methods used, for example, induction chemical, chemical concentration, and injection method (ip) were appropriate to cause EROD induction. There was no statistical difference in SDH activity in any species, thus liver function was not likely to be impaired.

The significant increase in EROD activity in the PCB 126 group over the Time Zero and Corn Oil Control groups indicates sand flathead to be a good indicator of pollution. Previous studies in which sand flathead were ip injected with $400 \mathrm{mg} / \mathrm{kg}$ of Aroclor 1254 showed maximum EROD induction increases of only fivefold (Brumley et al., 1995). The present study was able to induce EROD activity by up to 20 -fold in the PCB injected group, relative to controls, indicating that sand flathead can be an excellent biomonitoring tool. Sand flathead could be used in environmental monitoring of native Australian waters in a similar fashion to how the white sucker (Catostomus commersoni) is used in North America, and Pagothenia bernacchii in Antarctic environments. C. commersoni demonstrated EROD induction of 15 -fold in field studies investigating impacts of bleached kraft mill effluents exposure (Gagnon et al., 1994), while P. bernacchii showed a 65-fold EROD induction 10 days post injection with benzo( $\alpha$ )pyrene (Focardi et al., 1995).

3,3',4,4',5-pentachlorobiphenyl (PCB 126) has been used in many studies as a model inducing agent of $\mathrm{P} 5401 \mathrm{~A}$ in fish to examine the effects of various parameters such as dose and time of exposure (Palace et al., 1996), toxic equivalency factors (TEFs) (Newsted et al., 1995; Clemons et al., 1996; Hahn et al., 1996), and maximum induction potential (Janz and Metcalfe, 1991). Injection with PCB 126 also lead to high induction responses in the present study. In sand flathead, for which earlier studies exist, EROD induction was several times higher than previously reported (Holdway et al., 1990), further supporting the use of this species as a bioindicator tool.

The MFO induction levels observed for sixspine leatherjackets are not high enough to warrant this fish species being used in pollution monitoring programs using MFO as a biomarker. Difficulties in obtaining large numbers of individuals also support this conclusion, this fish's habitat limited to reef beds, with a small number of territorial individuals in each reef.

Bluethroat wrasse do not appear to make a good indicator species if EROD activity is used as a biomarker. EROD activity failed to be induced in the bluethroat wrasse injected with PCB 126, relative to both control groups. Prior to acclimation in clean laboratory waters, fish were kept for several days in the hull of a commercial fishing boat at a jetty. Oil and petroleum release from the many boats at the jetty may have been taken in by the boat's flow-through system in which fish were held, and complete depuration may not have occurred during the acclimation period. Petroleum compounds contain many inducing chemicals, including PAHs, which may be responsible for the relatively high EROD levels in the Time Zero Control group. Despite this high baseline level the PCB 126 group failed to achieve a higher EROD activity than the Corn Oil or Time Zero Control groups.

Induction can be affected by specific variables which have to be considered in any study. Some evidence exists that MS-222 anaesthesia can alter xenobiotic metabolizing enzymes (Fabacher, 1982) although other studies have concluded that anaesthesia does not affect the cytochrome P450 system (Kleinow et al., 1986). Brumley et al. (1995) used the same concentration and duration period of MS-222 on sand flathead as in the present study, and reported no effect on EROD levels. The use of anaesthesia was necessary for blood sampling and injections to be carried out while allowing the handling of vigorous and spiny fish.

Acclimation temperature has been reported to have a significant effect on both the level of induction and time required for induction (Förlin et al., 1984). Although the present study was conducted at different times of the year, water temperature differences of only $2.4^{\circ} \mathrm{C}$ were reported between any two species studied during experimentation (Table I). It is therefore assumed that water temperature was not a significant factor limiting EROD induction in the tested species.

In Australia, no endemic marine fish suitable for biomonitoring are yet available from reared stock, and consequently wild fish must be used. Of the indigenous species tested, sand flathead showed the highest MFO response and appear to be the most appropriate bioindicator species for pollution monitoring in Port Phillip Bay and surroundings.

The authors thank the staff of the Queenscliff Marine Station, especially Rod Watson for his technical assistance. The authors also thank Professor Douglas A. Holdway for constructive comments on this paper. 


\section{REFERENCES}

Adams, S. M.; Shepard, K. L.; Greeley, M. S., Jr.; Jimenez, B. D.; Ryon, M. G.; Stugart, L. R.; McCarthy, J. F. Mar Environ Res 1989, 28, 459-464.

Ahokas, J. T.; Holdway, D. A.; Brennan, S. E.; Goudey, R. W.; Bibrowska, H. B. Environ Toxicol Chem 1994, 13, 41-50.

Brumley, C. M.; Haritos, V. S.; Ahokas, J. T.; Holdway, D. A. Aquat Toxicol 1995, 31, 249-262.

Clemons, J. H.; Lee, L. E. J.; Myers, C. R.; Dixon, D. G.; Bols, N. C. Can J Fish Aquat Sci 1996, 53, 1177-1185.

Dixon, D. G.; Hodson, P. V.; Kaiser, K. L. E. Environ Toxicol Chem 1987, 6, 685-696.

Fabacher, D. L. Comp Biochem Physiol 1982, 73C, 277-283.

Fabris, G. J.; Monahan, C.; Nicholson, G.; Walker, T. L. Aust J Mar Freshwater Res 1992, 43, 1393-1402.

Focardi, S.; Fossi, M. C.; Lari, L.; Casini, S.; Leonzio, C.; Meidel, S. K.; Nigro, M. Mar Environ Res 1995, 39, 97-100.

Förlin, L.; Anderson, T.; Koivusaari, U.; Hansson, T. Mar Environ Res 1984, 14, 47-58.

Gagnon, M. M.; Dodson, J. J.; Hodson, P. V.; Van Der Kraak, G.; Carey, J. H. Can J Fish Aquat Sci 1994, 51, 337-347.

Hahn, M. E.; Woodward, B. L.; Stegeman, J. J.; Kennedy, S. W. Environ Toxicol Chem 1996, 15, 582-591.

Harris, G.; Batley, G.; Fox, D.; Hall, D.; Jernakott, P.; Molloy, R.; Murray, A.; Newell, B.; Parslow, J.; Skyring, G.; Walker, S. Port Phillip Bay environmental study final report, CS1RO: Canberra, Australia, 1996.

Hodson, P. V.; Kloepper-Sams, P. J.; Munkittrick, K. R.; Lockhart, W. I.; Metner, D. A.; Luxon, P. L.; Smith, I. R.; Gagnon, M. M.; Servos, M.; Payne, J. Can Tech Rep Fish Aquat Sci 1991, 1829.
Holdway, D. A.; Ahokas, J. T.; Bartholamaeus, A. R.; Butty, J. S.; Donohue, D. C.; Salminen, S. J. Clin Exp Pharm Phys Suppl 1990, 16, 169.

Holdway, D. A.; Brennan, S. E.; Ahokas, J. T. In 47th Appita Annual General Conference, Rotorua, NZ, pp. 779-789, 1993.

Holdway, D. A.; Brennan, S. E.; Ahokas, J. T. Mar Pollut Bull 1994, 28, 683-695.

Holdway, D. A.; Brennan, S. E.; Ahokas, J. T. Aust J Ecol 1995, 20, 34-44.

Janz, D. M.; Metcalfe, C. D. Environ Toxicol Chem 1991, 10, 917-923.

Kleinow, K. M.; Haasch, M. L.; Lech, J. J. Aquat Toxicol 1986, 8, 231-241.

Kloepper-Sams, P. J.; Benton, E. Environ Toxicol Chem 1994, 13, 1483-1496.

Lowry, O. H.; Rosebrough, N. J.; Farr, A. L.; Randall, R. J. J Biol Chem 1951, 193, 265-275.

Newsted, J. L.; Giesy, J. P.; Ankley, G. T.; Tillitt, D. E.; Crawford, R. A.; Gooch, J. W.; Jones, P. D.; Denison, M. S. Environ Toxicol Chem 1995, 14, 861-871.

Ozretic, B.; Krajnovic-Ozretic, M. Environ Contam Toxicol 1993, 50, 586-592.

Palace, V. P.; Klaverkamp, J. K.; Lockhart, W. L.; Metner, D. A.; Muir, C. G.; Brown, S. B. Environ Toxicol Chem 1996, 15, 955-960.

Payne, J. F.; Fancey, L. L.; Rahimtula, A. D.; Porter, E. L. Comp Biochem Physiol 1987, 88C, 233-245.

Phillips, D. J. F.; Richardson, B. J.; Murray, A. P.; Fabris, J. G. Mar Pollut Bull 1992, 25, 200-217.

Smith, J. D.; Bragg, J.; Wrigley, I. Wat Res 1991, 25, 1145-1150.

Zar, J. H. Biostatistical Analysis; second edition, PrenticeHall: New Jersey, 1984; p. 718. 